\title{
PKM Pemanfaatan Daur Ulang Sampah Non Organik Berbasis Ecobrick dalam Meningkatkan Ekonomi dan Kreativitas Santri Pondok Pesantren Nurul Jadid Wilayah Al-Mawaddah
}

\author{
Moh Idil Ghufron, ${ }^{1}$ Siti Maryam, ${ }^{2}$ Sri Nurul Ulif Al Inayah, ${ }^{3}$ Fitria, ${ }^{4}$ \\ Faizatul Aliyah, ${ }^{5}$ Yunita Nurmelinda, ${ }^{6}$ Sulis Nada, ${ }^{7}$
}

Universitas Nurul Jadid, Paiton Probolinggo 1234567

aidil.piero7@gmail.com,maryam12@gmail.com, ulifyaya@gmail.com, fitfitria@gmail.com, aliyafaiz@gmail.com, Melinda.y@gmail.com, sulisnada88@gmail.com

Submission: 01/09/2021 Received: 29/11/2021 Published: 31/12/2021

Keywords:

Trash, Creativity,

Pesantren, Santri

Katakunci:

Sampah,

Kreativitas,

pesantren, Santri
Abstract. Garbage is an item deemed unused and disposed of by the previous owner/user, but for some people it can still be used if it is managed with the right procedures. However, non-organic waste is often considered as environmental pollution due to industry and households. Therefore, this studen service activity is to make use of non-organic waste to be useful by making it creative to deal with scattered garbage. The method of counseling and training for santri the Al-Mawaddah area on how to make creativity such as flower pots and flowers from non-organic waste. The result obtained from this activity were: a) considerable enthesiasm from the students for the material the had been given, and b)increased knowledge of the students on the use of non-organic waste as a material fot creativity.

\begin{abstract}
Abstrak. Sampah non organik selama ini menjadi permasalahan hampir di setiap wilayah yang dampaknya dapat mengakibatkan banjir. Sampah yang tidak bisa terurai di dalam tanah mengakibatkan sebagian besar orang membuang sampah sembarangan dan menjadi penyebab utama terhadap rusaknya lingkungan di antaranya menimbulkan tersumbatnya saluran air ataupun sungai. Solusi terhadap penanganan sampah non organik yakni dengan mendaur ulang sampah menjadi kerajinan tangan salah satunya ecobrick. Ecobrick yaitu teknik mengolah sampah plastik menjadi sebuah benda yang bermanfaat dengan cara memasukkan sampah plastik ke dalam sebuah botol. Oleh karena itu, kegiatan ini merupakan pengabdian kepada santri dengan melakukan pendampingan memanfaatkan sampah non organik agar bernilai jual dengan cara menjadikannya kreativitas untuk mengatasi sampah yang dibuang sembarangan. Metode dalam pencapaian tujuan tersebut adalah metode penyuluhan dan pelatihan kepada santri Pondok Pesantren Nurul Jadid Wilayah al-Mawaddah tentang cara pembuatan kreativitas berbasis ecobrick seperti pot bunga serta bunga dari sampah non organik. Hasil capaian yang diperoleh dari kegiatan ini adalah: a) antusiasme yang cukup besar dari para santri terhadap materi yang telah diberikan, b) meningkatnya pengetahuan santri terhadap pemanfaatan sampah non organik sebagai bahan kreativitas, dan c) santri memiliki kemampuan untuk membuat produk untuk dijual.
\end{abstract}




\section{Pendahuluan}

Sampah berbahan non organik atau biasa dikatakan sampah plastik merupakan salah satu masalah lingkungan utama di Indonesia. Hampir di seluruh penjuru negeri masalah sampah menjadi momok yang sangat sulit dihindari. Mengutip dari HM. Asih bahwa Kepala Biro Hubungan Masyarakat - Kementerian Lingkungan Hidup dan Kehutanan menyatakan bahwa Indonesia merupakan peringkat kedua di dunia penghasil sampah plastik ke laut setelah Tiongkok yaitu sebanyak 10,95 juta lembar sampah kantong plastik yang sama artinya dengan luasan 65,7 Ha kantong plastik atau 60 kali luas lapangan sepakbola. (Asih, H. M., \& Fitriani, S. 2018)

Plastik banyak digunakan dalam berbagai macam kebutuhan hidup manusia. Mulai dari bahan untuk membungkus makanan hingga keperluan bahan rumah tangga dan industri. Plastik merupakan sebuah bahan yang paling populer dan paling banyak digunakan dikarenakan praktis dan mudah untuk menjadi wadah atau bungkus dari barang-barang dan ringan untuk dibawa.

Limbah plastik yang menjadi tumpukan sampah berasal dari kemasan makanan dan minuman, kantong atau bungkus belanja.

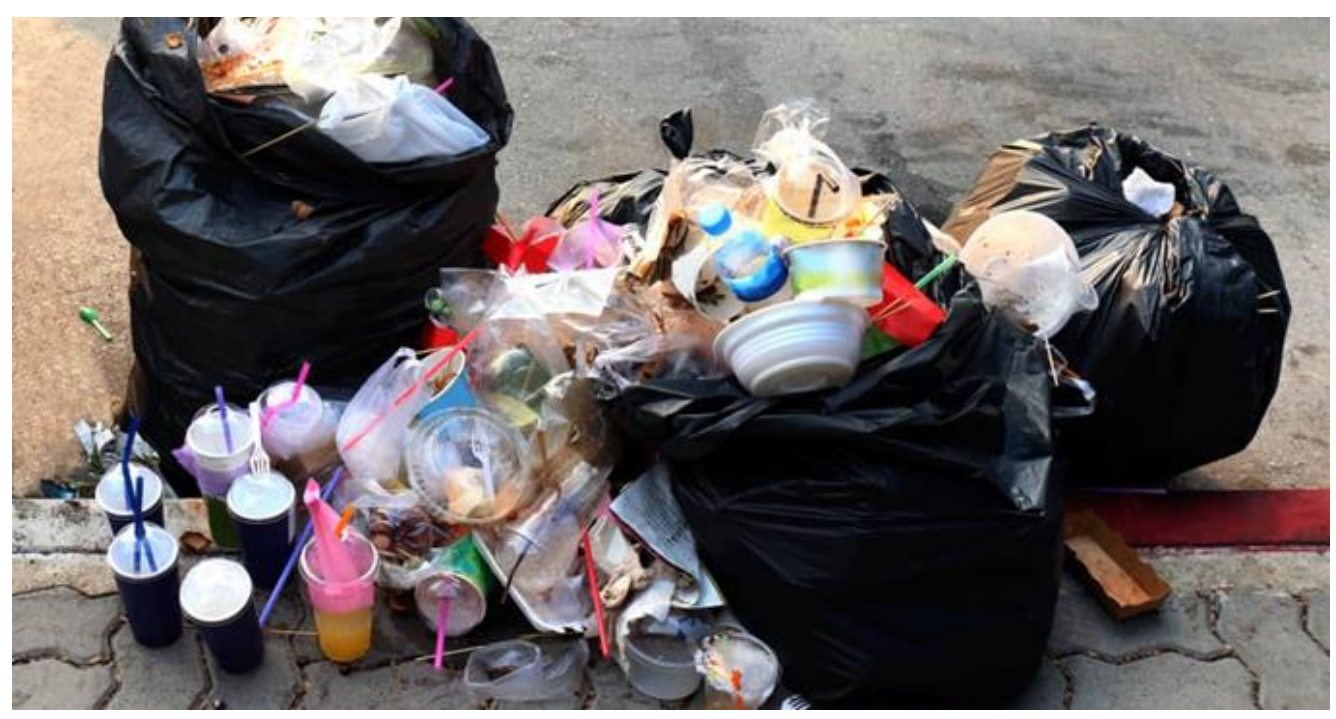

Gambar 1. Salah satu sampah yang banyak ditemui di pesantren 
Sampah bermula dari masyarakat tidak bertanggung jawab yang membuang sampah kantong plastik sembarangan seperti membuang sampah di sungai, pantai dan laut, atau di lahan kosong, kegiatan yang tidak bertanggung jawab ini nantinya akan berdampak buruk kepada lingkungan seperti bencana banjir, tercemarnya sungai dan pantai hingga terganggunya biota laut, memunculkan berbagai macam penyakit bahkan menyebabkan tanah tidak subur. Menurut Hadi (2018), timbunan plastik, hanya $10-15 \%$ saja yang telah didaur ulang, 60-70\% ditimbun di tempat pembuangan akhir, dan 15-30\% belum terkelola sampai terbuang ke lingkungan terutama perairan seperti sungai, danau, pantai, dan laut.

Pengabdian ini bermula dari permasalahan yang ada pada Pondok pesantren sebagai wadah pendidikan berbasis agama dan budi pekerti yang baik untuk mencapai pembelajaran yang baik sudah semestinya menjadikan lingkungan yang baik pula, terlebih dengan adanya slogan "annadhofau minal iman atau kebersihan sebagian dari iman" sudah melekat di dunia pesantren. Dengan adanya slogan seperti itu pondok pesantren sudah semstinya menjadi cerminan untuk membuktikan dengan langkah-langkah kemandirian dalam bertanggung jawab akan lingkungan.

Cara menanggulangi hal tersebut pendampingan dilakukan di pondok pesantren nurul jadid wilayah Al-mawaddah melakukan pemanfaatan daur ulang sampah non organik melalui ecobrik. "eco" dan "brick" artinya bata ramah lingkungan.

Dengan adanya pendampingan pemberdayaan kepada santri wilayah alMawaddah diharapkan dapat mendorong kreativitas santri dan ekonomi sehingga akan menjadi percontohan bagi wilayah lain maupun pondok pesantren lain dalam memanfaatkan sampah menjadi sesuatu yang bernilai jual.

latar belakang yang telah di paparkan di atas menjadi alasan memilih dampingan sehingga dapat diidentifikasi sebagai berikut:

1. Banyak ditemuinya sampah di beberapa tempat khususnya di pondok pesantren

2. Masih minim kesadaran santri maupun wali santri untuk menjaga kebersihan 
3. Pondok pesantren dikenal dengan slogan kebersihan Sebagian daripada Iman namun berbeda di lapangan bahwa masih banyak pondok pesantren yang minim dalam pengelolaan sampah secara teratur dan tertib

4. Pondok pesantren Nurul Jadid wilayah al-Mawaddah diharapkan menjadi percontohan dengan adanya pemilahan tempat sampah yang dapat didaur ulang dan tidak dapat didaur ulang.

5. Sebagai pembelajaran kepada santri di Pondok Pesantren Nurul jadid bahwa dari sampah dapat menjadi berkah

\section{Metode}

Penelitian deskriptif mengumpulkan data berdasarkan faktor-faktor yang menjadi pendukung objek penelitian, kemudian menganalisisnya untuk mencari peranannya Arikunto (2010:151).

Dalam penelitian ini peneliti mengkaji implementasi pemanfaatan daur ulang sampah non organik berbasis ecobrick sebagai bentuk untuk meningkatkan ekonomi dan kreativitas santri. Objek penelitian ini adalah di Pesantren Nurul Jadid Wilayah al-Mawaddah yang terletak di Karanganyar Paiton. Analisis data dalam penelitian ini dilakukan dengan teknik Observasi, Pendampingan, Wawancara dan dokumentasi.

Teknik Observasi dilakukan sebagai peninjauan awal guna melihat dan mencermati keadaan situasi lapangan yang akan di berikan pendampingan. Teknik wawancara digunakan untuk mengumpulkan data pelaksanaan program pemanfaatan sampah non organik berbasis ecobrick pada tahapan pengolahan data santri, tahapan pemberdayaan santri terhadap pemanfaatan sampah non organik di. Data dokumentasi digunakan untuk mengumpulkan data kondisi sampah di wilayah al-Mawaddah dan tempat pemilahan sampah organik dan non organik.

Pada penelitian kali ini, teknik dokumentasi yang digunakan bersumber dari data santri pesantren Nurul Jadid wilayah al-Mawaddah Karanganyar Paiton. Selain itu, dokumentasi juga diambil dari dokumen hasil kegiatan pelatihan pembuatan kreativitas berbasis ecobrick, sedangkan dokumentasi 
berupa foto diambil pada saat pelaksanaan kegiatan yang berlangsung di wilayah al-Mawaddah.

Kegiatan pengabdian ini dilakukan dengan beberapa langkah sebagai berikut:

a. observasi lokasi kegiatan

observasi dilakukan dengan tujuan untuk menentukan tempat yang tepat dalam melaksanakan kegiatan pengabdian ini. survei kegiatan yang dilakukan pemilihan sampah non-organik yang digunakan sebagai kreativitas bunga dan pot bunga serta lokasi di mana akan dilaksanakannya kegiatan. Negosiasi dengan kepala Pondok Pesantren Nurul Jadid Wilayah Al-Mawaddah dan sebagai mitra dalam pelaksanaan kegiatan PKM dengan tujuan untuk menentukan jadwal, tempat dan persepsi yang sama tentang kegiatan.

b. Survei bahan baku untuk pelaksanaan kegiatan

Survei bahan baku bertujuan untuk memastikan bahan yaitu sampah non organik. Bahan utamanya dalam pembuatan kreativitas dari sampah non-organik yaitu seperti botol minuman, plastik, dan lain-lain.

c. Identifikasi dan Pengumpulan data pendukung kegiatan

Pengumpulan data pendukung dilakukan untuk memantau kegiatan pimilahan sampah yang dilakukan oleh rekan santri selama kegiatan ini, sehingga arahan dalam pelaksanaan kegiatan benar-benar bermanfaat bagi santri setempat di Pondok Pesantren Nurul Jadid Wilayah Al-Mawaddah.

d. Pengkajian produk oleh Tim

Sebelum pelaksanaan kegiatan, tim perlu melakukan uji coba terhadap produk untuk memastikan kualitas produk yang akan dibuat dalam kegiatan.

e. Sosialisasi tentang pemanfaatan sampah non-organik

Kegiatan pengabdian kepada santri ini pembuatan kreativitas bunga dan pot bunga dari sampah non-organik. Hal ini bertujuan agar santri 
dapat memahami cara membuat kreativitas dari sampah non organik tersebut.

f. Pendampingan pembuatan kreativitas dari sampah non-organik

Pada saat kegiatan PKM praktik pembuatan kreativitas bunga dan pot bunga dalam kegiatan ini bertujuan agar santri kegiatan dapat mengetahui bahan yang digunakan secara langsung untuk pembuatan dan cara membuat kreativitas dari sampah non organik sehingga diharapkan santri dapat membuat dengan benar di kemudian hari.

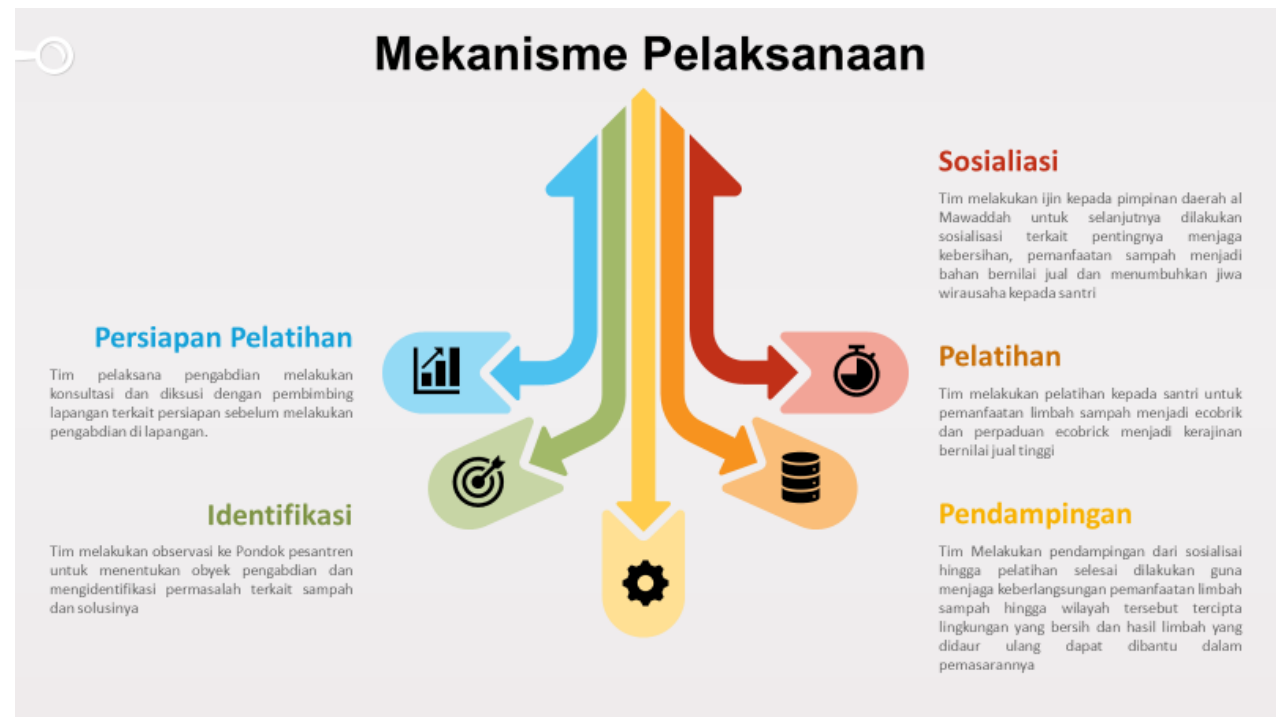

\section{Hasil}

Program pengabdian kepada masyarakat ini dilaksanakan di Pondok Pesantren Nurul Jadid Wilayah al-Mawaddah Desa Karanganyar Kecamatan Paiton Kabupaten Probolinggo Provinsi Jawa Timur. Wilayah Al Mawaddah ialah merupakan wilayah yang berada di bawah naungan Pondok Pesantren Nurul Jadid sebagai tempat membina santriwati dari berbagai jenjang pendidikan mulai tingkat SLTP, SLTA, Perguruan Tinggi hingga Khorijat (santri yang tidak sekolah formal). Untuk lebih mengoptimalkan pembinaan dan pendidikan santri, wilayah al-Mawaddah telah melaksanakan pemetaaan dan pengelompokan di dalam proses pembelajaran yang sesuai dengan minat bakat dan kecenderungan masing-masing santri, serta merupakan beberapa program khusus/unggulan. Masing-masing program ini mempunyai 
ketentuan, target dan output tertentu, yang harus dicapai oleh santri sesuai dengan program keahlian pilihan masing-masing.

Dalam upaya mencetak santri yang berkualitas dan siap berkhidmah untuk agama, bangsa dan negara, Wilayah al-Mawaddah juga telah melaksanakan pembinaan intensif untuk mengasah Leadership dan Managemen santri serta mengembangkan skill tertentu yang dapat menunjang kemampuan dan kiprahnya setelah kembali ke tengah-tengah masyarakat.

Dewasa ini, wilayah al-Mawaddah juga memiliki sumber daya insani (SDI) yang dinamakan dengan santriprenuership. Maka dari itu, wilayah Al mawaddah membuka usaha roti, usaha kuliner serta juga air mineral dan sebagainya. Berbekal keinginan wilayah al-Mawaddah tersebut terus melangkah maju ke realisasi usaha memproduksi roti.

Santri yang berada di wilayah al Mawaddah ini berkisar di antara 500 hingga 1000 santri yang berpotensi dapat menghasilkan sampah yang banyak sehingga pihak pengurus menyediakan tempat sampah dan tenaga yang intens untuk membuang sampah tepat waktu menghindari sampah yang menumpuk.

Dengan melihat kondisi tersebut terobosan yang dilakukan oleh pihak pengurus yakni dengan adanya pemilahan tempat sampah sehingga memudahkan dalam membuang sampah yang berpotensi cepat bau dan rawan dihinggapi nyamuk dan lalat yang menimbulkan berbagai macam penyakit.

Kegiatan pengabdian kepada masyarakat ini didahului dengan observasi lapangan. Hasil wawancara dengan kepala wilayah al-Mawaddah dan beberapa santri yang diambil sebagai sampel dapat diambil kesimpulannya, bahwa santri banyak yang menggunakan atau membeli barang yang dibungkus dengan plastik terlebih pada saat pandemi sekarang santri diharuskan untuk tidak makan dan minum dengan bekas pakai teman atau orang lain, sehingga banyak sekali ditemukan sampah sampah non-organik.

Dari hasil observasi juga diketahui bahwa di wilayah al-Mawaddah terdapat program pemilahan antara sampah organik dan non organik sehingga memudahkan tim untuk melakukan pengabdian dengan pelatihan pembuatan kreativitas ecobrick. 
Seperti yang dijelaskan dalam metode pengabdian, tim melakukan koordinasi awal dengan dosen pembimbing untuk judul pengabdian dan strategi yang akan dilakukan dalam pengabdian. Hasil dari bimbingan diputuskan bahwa obyek pengabdian yakni di Pondok Pesantren Nurul Jadid Wilayah al-Mawaddah dan yang dijadikan judul pengabdian adalah Pemanfaatan Daur Ulang Sampah Non Organik Berbasis Ecobrick dalam Meningkatkan Ekonomi dan Kreativitas Santri Pondok Pesantren Nurul Jadid Wilayah Al-Mawaddah.

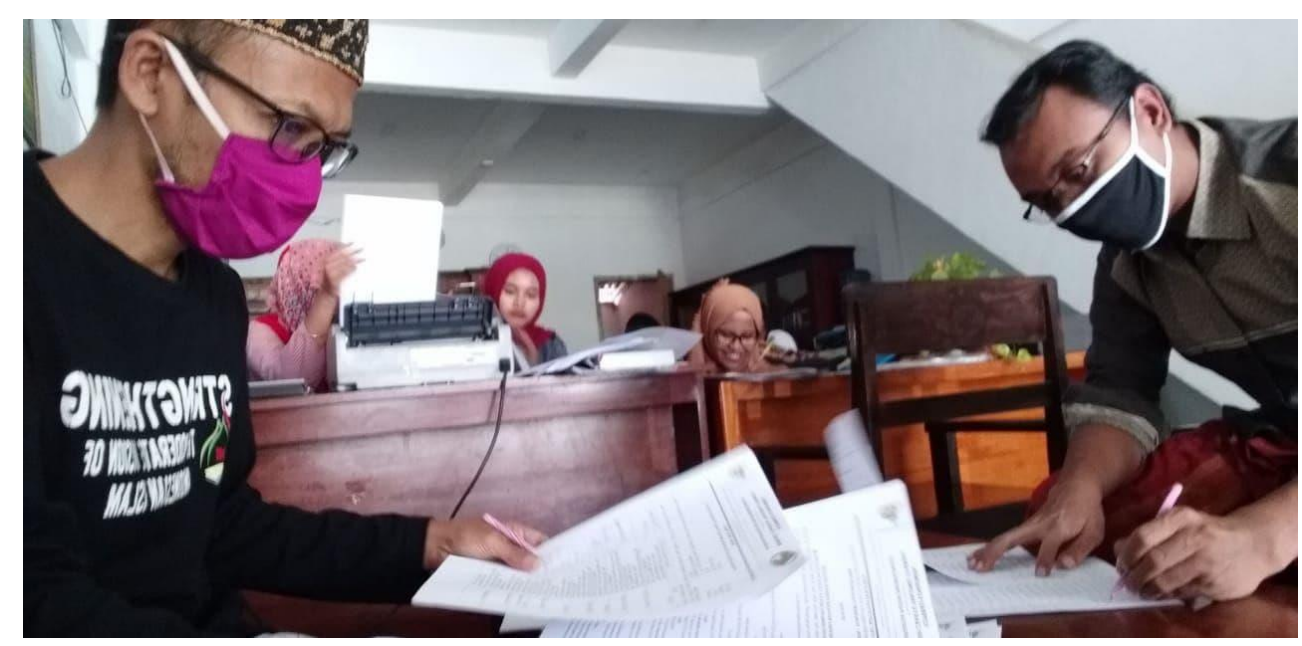

Gambar 2: Proses Bimbingan dengan Dosen Pembimbing Lapangan menentukan obyek dan judul pengabdian

Kemudian setelah selesai melakukan bimbingan, tim melakukan observasi ke wilayah-wilayah yang ada di pondok pesantren nurul jadid termasuk salah satunya adalah obyek pengabdian di wilayah al-Mawaddah. 


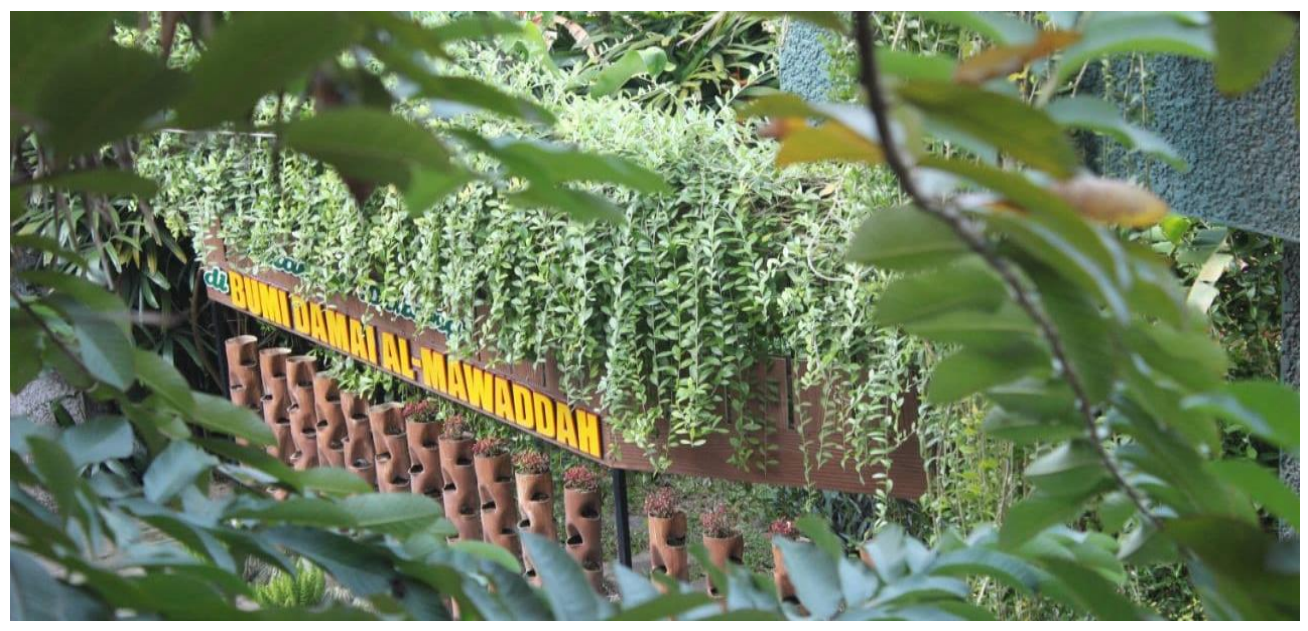

Gambar 3: Observasi ke wilayah Al-Mawaddah

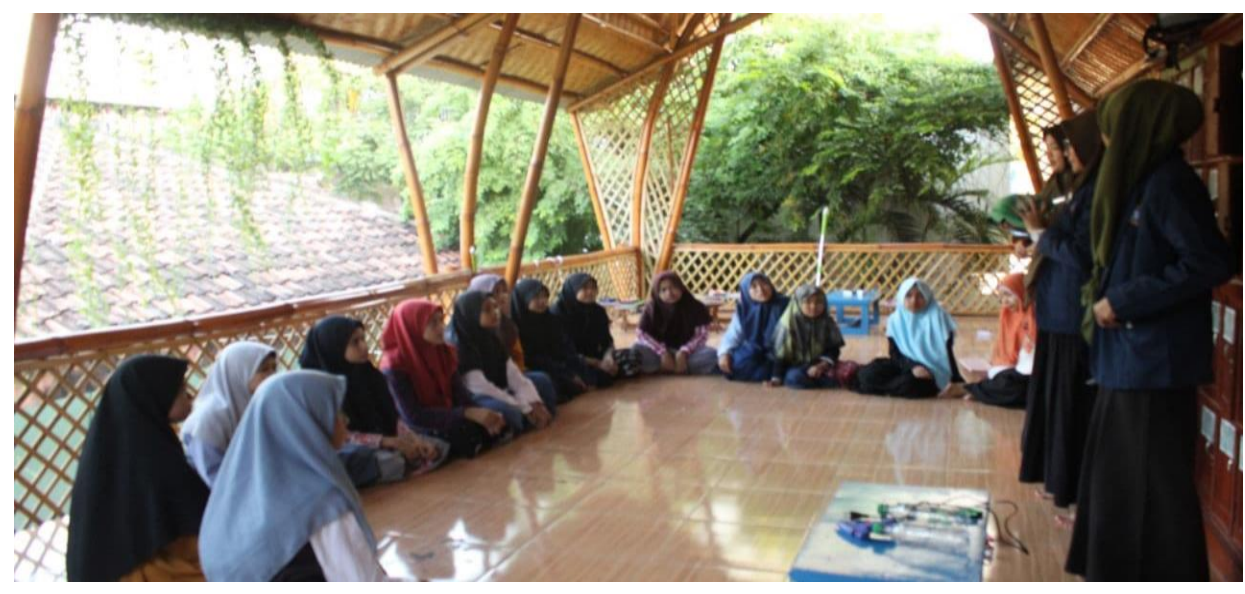

Gambar 4: Sosialisasi tentang pengabdian dan mengajak santri untuk menjadi wirausaha

Langkah selanjutnya yakni melakukan sosialisasi kepada santri yang ada di wilayah al-Mawaddah untuk menjelaskan tujuan dari adanya pengabdian dan alasan melakukan pengabdian dengan memanfaatkan sampah non organik dan pentingnya menjaga kebersihan lingkungan serta dengan adanya pemanfaatan limbah tersebut dapat membuat bahan tidak berguna menjadi bahan yang bernilai jual dengan menjadikan berbagai macam kerajinan tangan.

Pelatihan pembuatan produk dari sampah non organik menjadi agenda selanjutnya agar santri di samping paham dalam membuat produk diharapkan juga untuk dapat berkreasi dalam model produk sehingga produk tersebut 
memiliki nilai jual lebih tinggi dari sekedar ecobrick saja, santri juga diajarkan cara memperoleh ide dalam membuat hasil kerajinan tangannya sehingga banyak hasil kerajinan yang dihasilkan.
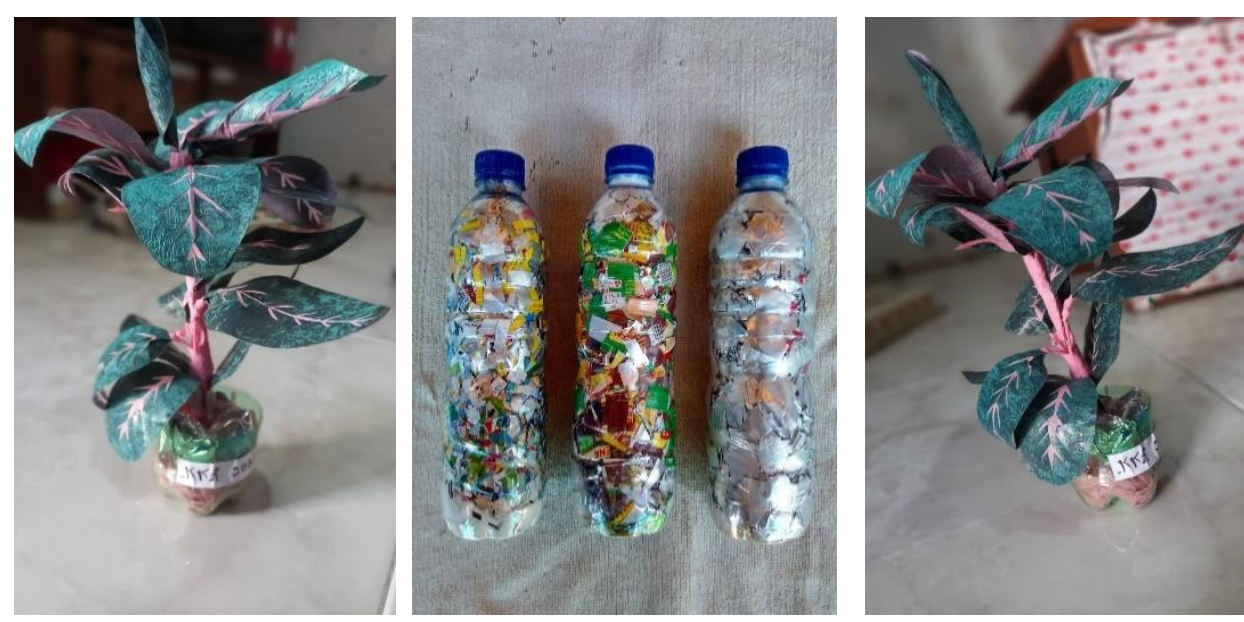

Gambar 5: Hasil PelatihanPembuatan kerajinan tangan berbasis ecobrick di Wilayah al-Mawaddah

Evaluasi dilakukan dalam bentuk kontrol pendampingan yang bertujuan agar santri tetap dapat melanjutkan kegiatan ini walaupun pelaksanaan pengabdian telah usai. Diharapakan wilayah al-Mawaddah menjadi role model bagi wilayah lain di pondok pesantren Nurul Jadid serta pondok pesantren lainnya.

Adapun jadwal dari kegiatan pengabdian ini sebagaimana table di bawah ini: 


\begin{tabular}{|c|c|c|c|c|c|c|c|c|c|c|c|c|}
\hline \multirow{2}{*}{$\begin{array}{l}\mathrm{N} \\
0 \\
1\end{array}$} & \multirow[t]{2}{*}{ Uraian } & \multicolumn{11}{|c|}{ Bulan Pelaksanaan } \\
\hline & & \multicolumn{4}{|c|}{ Februari } & \multicolumn{4}{|c|}{ Maret } & \multicolumn{3}{|c|}{ April } \\
\hline & $\begin{array}{l}\text { Tim pelaksana pengabdian } \\
\text { melakukan konsultasi dan } \\
\text { diksusi dengan pembimbing } \\
\text { lapangan terkait persiapan } \\
\text { sebelum melakukan } \\
\text { pengabdian di lapangan. }\end{array}$ & V & V & & & & & & & & & \\
\hline 2. & $\begin{array}{l}\text { Tim melakukan observasi ke } \\
\text { Pondok pesantren untuk } \\
\text { menentukan obyek } \\
\text { pengabdian dan } \\
\text { mengidentifikasi permasalah } \\
\text { terkait sampah dan solusinya }\end{array}$ & & & V & V & & & & & & & \\
\hline 3. & $\begin{array}{l}\text { Tim melakukan ijin kepada } \\
\text { pimpinan daerah al- } \\
\text { Mawaddah untuk selanjutnya } \\
\text { dilakukan sosialisasi terkait } \\
\text { pentingnya menjaga } \\
\text { kebersihan, pemanfaatan } \\
\text { sampah menjadi bahan } \\
\text { bernilai jual dan } \\
\text { menumbuhkan jiwa wirausaha } \\
\text { kepada santri }\end{array}$ & & & & V & V & & & & & & \\
\hline 4. & $\begin{array}{l}\text { Tim melakukan pelatihan } \\
\text { kepada santri untuk } \\
\text { pemanfaatan limbah sampah } \\
\text { menjadi ecobrik dan } \\
\text { perpaduan ecobrick menjadi } \\
\text { kerajinan bernilai jual tinggi }\end{array}$ & & & & & & V & $\mathrm{V}$ & V & & & \\
\hline 5. & $\begin{array}{l}\text { Tim Melakukan pendampingan } \\
\text { dari sosialisai hingga pelatihan } \\
\text { selesai ilakukan guna menjaga } \\
\text { keberlangsungan pemanfaatan } \\
\text { limbah sampah hingga wilayah } \\
\text { tersebut tercipta lingkungan } \\
\text { yang bersih dan hasil limbah } \\
\text { yang didaur ulang dapat } \\
\text { dibantu dalam pemasarannya }\end{array}$ & & & & & & & & & & V & V \\
\hline
\end{tabular}

Berdasarkan kondisi saat ini di Pondok Pesantren Nurul Jadid wilayah alMawaddah merupakan salah satu wilayah yang ada di pondok pesantren dengan jumlah santri yang banyak sehingga dapat menciptakan tumpukan 
sampah dari sisa makan dan minum santri hingga wali santri yang datang pada saat berkunjung ke pondok pesantren.

Dan dengan adanya pemetaan tempat sampah yang telah dilakukan oleh pihak wilayah kegiatan Program Pengabdian Kepada Masyarakat ini tentunya memiliki target dan output sebagai wujud dari pemberdayaan kreativitas santri selain menjaga kebersihan lingkungan. Adapun target dan luaran yang di hasilkan dari kegiatan dapat dilihat pada Tabel 1.

Tabel 1. Target dan Luaran program pengabdian

\begin{tabular}{|c|c|}
\hline$\tau$ & Output \\
\hline $\begin{array}{l}\text { 1. Menciptakan iklim yang kondusif dan } \\
\text { sehat di lingkungan Pondok } \\
\text { pesantren }\end{array}$ & $\begin{array}{l}\text { 1. Membentuk dan menumbuh } \\
\text { kembangkan santri secara partisipatif } \\
\text { (dari, untuk dan oleh santri) }\end{array}$ \\
\hline $\begin{array}{l}\text { 2. Menumbuhkembangkan kreativitas } \\
\text { santri untuk memanfaatkan setiap } \\
\text { peluang, informasi, dan akses } \\
\text { pengetahuan yang dalam hal ini } \\
\text { memanfaatkan sampah }\end{array}$ & $\begin{array}{l}\text { 2. Meningkatkan kemampuan santri } \\
\text { untuk melakukan Gerakan perubahan } \\
\text { melalui cara yang kreatif dan inovatif } \\
\text { dengan melihat kondisi di sekitar } \\
\text { berorientasi kepada kepada IPTEK dan } \\
\text { menghargai konsep serta prestasi. }\end{array}$ \\
\hline $\begin{array}{l}\text { 3. Membantu memperlancar proses } \\
\text { dalam mengidentifikasi kebutuhan } \\
\text { dan masalah serta Menyusun } \\
\text { rencara dan memecahkan masalah } \\
\text { yang dihadapi di dalam pesantren } \\
\text { khususnya terkait kebersihan dan } \\
\text { kreativitas santri }\end{array}$ & $\begin{array}{l}\text { 3. Memberikan keterampilan tentang } \\
\text { Langkah-langkah yang harus ditempuh } \\
\text { dalam mengidentifikasi dan } \\
\text { menyelesaikan permasalahan dengan } \\
\text { memanfaatkan sumber informasi yang } \\
\text { akurat }\end{array}$ \\
\hline $\begin{array}{l}\text { 4. Meningkatkan kemampuan dalam } \\
\text { membaca peluang ekonomi yang } \\
\text { dihasilkan dari ide sampah guna } \\
\text { memberikan keuntungan kepada } \\
\text { santri berupa bekal wirausaha dan } \\
\text { keuntungan materi untuk } \\
\text { pengembangan pondok pesantren }\end{array}$ & $\begin{array}{l}\text { 4. Meningkatkan system jejaring kerja } \\
\text { yang lebih luas agar nantinya mudah } \\
\text { mendapat informasi yang up to date } \\
\text { dan responsif terhadap perubahan di } \\
\text { bidang ekonomi }\end{array}$ \\
\hline $\begin{array}{l}\text { 5. Menumbuhkembangkan Kerjasama } \\
\text { antar santri dalam memberi bekal } \\
\text { wawasan kewirausahaan agar } \\
\text { mampu berinteraksi di dalam dunia } \\
\text { kerja secara berkelanjutan pada saat }\end{array}$ & $\begin{array}{l}\text { 5. Menempatkan bimbingan dan } \\
\text { dukungan yang diarahkan kepada } \\
\text { seluruh santri agar melek informasi } \\
\text { dan mau untuk belajar berinovasi } \\
\text { kepada sesuatu yang ada disekitar }\end{array}$ \\
\hline
\end{tabular}




\section{Pembahasan}

Sampah menjadi momok untuk kebanyakan orang dikarenakan banyak menimbulkan banyak masalah. Perlu adanya perubahan-perubahan yang dapat meminimalisir terjadinya masalah-masalah yang akan menimbulkan kerugian besar yang berdampak kepada lingkungan, ekonomi dan sosial ekonomi.

Ecobrick merupakah salah satu terobosan dalam menanggulangi problem sampah. Ecobrick diartikan sebagai kreativitas dari botol yang berbahan plastik yang dibingkai dengan cara memotong plastik kecil-kecil dan memasukkan potongan tersebut dengan memadatkan hingga memenuhi seluruh botol yang dapat digunakan untuk membuat suatu karya seni maupun bangunan yang berdaya guna tinggi. Berdasarkan pengertian yang dijelaskan melalui website ecobrick.org, selain menggunakan plastik, ecobrick dapat dibuat menggunakan bahan yang sama- sama tidak dapat didaur ulang dan membahayakan lingkungan seperti Styrofoam, kabel, baterai kecil, dan lain-lain. Namun selama ini pembuatan ecobrick masih dominan dengan memanfaatkan limbah plastik. Ecobrick dapat dimanfaatkan sebagai furnitur (kursi, meja), ruang tanam, dinding, bahkan sebuah bangunan secara utuh (Antico, Wiener, Araya-Letelier, \& Gonzalez Retamal, 2017).

Menciptakan kreativitas dengan konsep ecobrick sangatlah mudah, hanya dengan mengumpulkan sampah plastik yang ditambah dengan bahan lainnya berupa gunting, batang kayu sebagai pemadat. Ecobrick itu sendiri hanya bisa diisi dengan sampah anorganik. Sampah plastik tersebut digunting menjadi lebih kecil agar mudah dimasukkan kedalam mulut botol hingga terisi penuh, kemudian botol tersebut ditekan menggunakan pemadat kayu hingga botol tersebut keras, padat dan terisi penuh dengan plastik. Ini bertujuan agar produk ecobrik tidak mudah penyok.

Sampah non organik merupakan hasil dari bahan buangan suatu proses produksi baik industri maupun rumah tangga. Pemukiman yang padat penduduk pasti menghasilkan pelbagai bahan buangan yang kian menumpuk menyebabkan sebuah polutan, baik polutan padatan maupun cairan dan gas. Salah satu polutan padatan berupa limbah plastik, sedangkan polutan cairan dan gas dapat berupa limbah kamar mandi, air sabun dan ada air buangan dari berbagai aktivitas rumah tangga lainnya.

Bila dilihat secara senyawa kimianya, limbah ini terdiri dari bahan kimia Senyawa organik dan senyawa anorganik. Dari adanya limbah tersebut dapat 
berdampak negatif terhadap lingkungan terutama bagi kesehatan manusia yang berakibat kepada munculnya bahaya keracunan yang ditimbulkan oleh limbah tergantung pada jenis dan karakteristik limbah.

\section{Tahapan pertama yakni proses pendampingan pemanfaatan sampah non} organik yang dapat digunakan untuk ecobrick

Pendampingan pemanfaatan sampah non organik berbasis ecobrick yang dilaksanakan di wilayah al-Mawaddah selain sebagai upaya meminimalisir terjadinya penyakit akibat tumpukan sampah, dapat dijadikan kreativitas santri dan peningkatan ekonomi santri.

Kegiatan ini didampingi atas program Lembaga Penerbitan, Penelitian, dan Pengabdian Masyarakat (LP3M) Universitas Nurul Jadid Paiton Probolinggo, mengeluarkan izin kepada Mahasiswa untuk melaksanakan kegiatan Pendampingan. Selanjutnya, tim Pendampingan melakukan observasi di wilayah-wilayah di Pesantren Nurul jadid Karanganyar, Paiton, Probolinggo. Selanjutnya tim menentukan tempat untuk dilakukan pendampingan melalui data yang dikumpulkan yang sesuai dengan kriteria-kriteria di antaranya wilayah yang mempunyai tempat pemilahan sampah organik dan non organik yang dalam hal ini wilayah alMawaddah masuk dalam kriteria tersebut. Tim Pendampingan berkoordinasi untuk mendapatkan ijin dengan pimpinan wilayah. Setelah memperoleh ijin pelaksanaan pendampingan pemanfaatan sampah non organik berbasis ecobrick di laksanakan sekitar 3 bulan dimulai dari bulan februari, Maret dan April.

Dampak Perubahan pada aspek proses pemberdayaan pemanfaatan sampah non organik berbasis ecobrick di wilayah al-Mawaddah Pondok Pesantren Nurul Jadid Karanganyar, Paiton, Probolinggo

Pada tahapan ini, tim melakukan survei ke wilayah al-Mawaddah untuk melihat kondisi sampah yang ada yang nantinya akan digunakan dalam pelaksanaan ecobrick.

Sebagaimana diketahui, Sampah adalah suatu bahan yang terbuang atau dibuang dari sumber hasil aktivitas manusia maupun proses alam yang belum memiliki nilai ekonomis. (Novi Marliani, 2014)

Berdasarkan asalnya, sampah padat dapat digolongkan sebagai: 
1. Sampah organik adalah sampah yang berasal dari sisa mahkluk hidup yang mudah terurai secara alami tanpa proses campur tangan manusia untuk dapat terurai. Sampah organik bisa dikatakan sebagai sampah ramah lingkungan bahkan sampah bisa diolah kembali menjadi suatu yang bermanfaat bila dikelola dengan tepat. Tetapi sampah bila tidak dikelola dengan benar akan menimbulkan penyakit dan bau yang kurang sedap hasil dari pembusukan sampah organik yang cepat (Chandra, 2006). Sampah Organik terdiri dari bahan-bahan penyusun tumbuhan dan hewan yang diambil dari alam atau dihasilkan dari kegiatan pertanian, perikanan atau yang lain. Sampah ini dengan mudah diuraikan dalam proses alami. Sampah rumah tangga sebagian besar merupakan bahan organik. Termasuk sampah organik, misalnya sampah dari dapur, sisa tepung, sayuran, kulit buah, dan daun.

2. Sampah non organik berasal dari sumber daya alam tak terbaharui seperti mineral dan minyak bumi, atau dari proses industri. Beberapa dari bahan ini tidak terdapat di alam seperti plastik dan aluminium. Sebagian zat anorganik secara keseluruhan tidak dapat diuraikan oleh alam, sedang sebagian lainnya hanya dapat diuraikan dalam waktu yang sangat lama. Sampah jenis ini pada tingkat rumah tangga, misalnya berupa botol, botol plastik, tas plastik, dan kaleng. (Agus Taufiq, 2015)

Ditinjau dari kepentingan kelestarian lingkungan, sampah yang bersifat organik tidak begitu bermasalah karena dengan mudah dapat dirombak oleh mikrobia menjadi bahan yang mudah menyatu kembali dengan alam. Sebaliknya sampah anorganik sukar terombak dan menjadi bahan pencemar. Pencemaran lingkungan umumnya berasal dari sampah yang menumpuk pada suatu tempat penampungan atau pembuangan. Perombakan sampah organik dalam suasana anaerob [miskin oksigen] akan menimbulkan bau tak sedap. Makin tinggi kandungan protein dalam sampah, makin tak sedap bau yang ditimbulkan. Dampak lain karena timbunan sampah dalam jumlah besar adalah lingkungan yang kotor dan pemandangan yang kumuh (Ihsan Febriadi, 2019).

Langkah awal yang dilakukan tim yakni define. Tim melakukan penentuan topik pendampingan dari berbagai temuan yang ada di lapangan yang diputuskan dengan pembuatan ecobrick yang selanjutnya dikoordinasikan dengan pimpinan wilayah. Dilanjutkan dengan dengan pemilahan sampah 
tersebut, diharapkan dapat mempermudah santri dalam mengetahui sampah yang dapat didaur ulang maupun yang tidak dapat didaur ulang. Setelah mengetahui hal tersebut, tim melakukan sosialisasi kepada santri dalam pembuatan ecobrick

Langkah kedua Dalam kegiatan pengabdian kepada masyarakat ini, selain penentuan tema pembuatan ecobrick, dilakukan juga pelatihan pembuatan ecobrick. Adapun langkah-langkah pembuatannya adalah sebagai berikut:

1. Menyiapkan alat dan bahan yang dihasilkan dari sampah non organik

2. Menggunting kecil-kecil sampah plastik yang sudah dibersihkan

3. Memasukkan dan merapatkan potongan sampah plastik ke dalam botol bekas yang telah disediakan

Beberapa ketentuan yang tidak boleh terlewarkan dalam membuat ecobrick, diantaranya:

1. Menggunakan ukuran botol yang sama agar dapat lebih mudah dimanfaatkan kemudian.

2. Berat minimum ecobrick berdasarkan botol plastik yang digunakan yaitu $500 \mathrm{ml}$ atau 0.5 liter menjadi 175 gram, $1000 \mathrm{ml}$ atau 1 liter menjadi 350 gram, 1500 ml atau 1.5 liter menjadi 525 gram, dan 1750 $\mathrm{ml}$ atau 1.75 liter menjadi 613 gram (www.ecobrick.org).

3. Merapatkan potongan sampah plastik hingga benar-benar memadat atau tidak ada ruang kosong lagi di dalamnya. Hal tersebut dimaksudkan agar ecobrick yang dihasilkan benar- benar kokoh.

4. Memastikan bahwa botol plastik maupun sampah plastik yang digunakan dalam keadaan bersih dan kering.

Dampak hasil dari pemberdayaan pemanfaatan sampah non organik berbasis ecobrick di wilayah al-Mawaddah Karanganyar, Paiton, Probolinggo

Proses pemberdayaan pemanfaatan sampah non organik berbasis ecobrick berdampak kepada:

1. Budaya menjaga lingkungan yang bersih dan asri dengan membuang sampah kepada tempatnya dan memanfaatkan sampah non organik menjadi ecobrick

2. Menjadikan lingkungan wilayah al-Mawaddah dipenuhi dengan hasil olahan kreativitas santri berbasis ecobrick 
3. Menjadikan ecobrick bernilai jual sehingga menambah semangat santri untuk menjadikan sampah non organik kepada kerajinan tangan lainnya

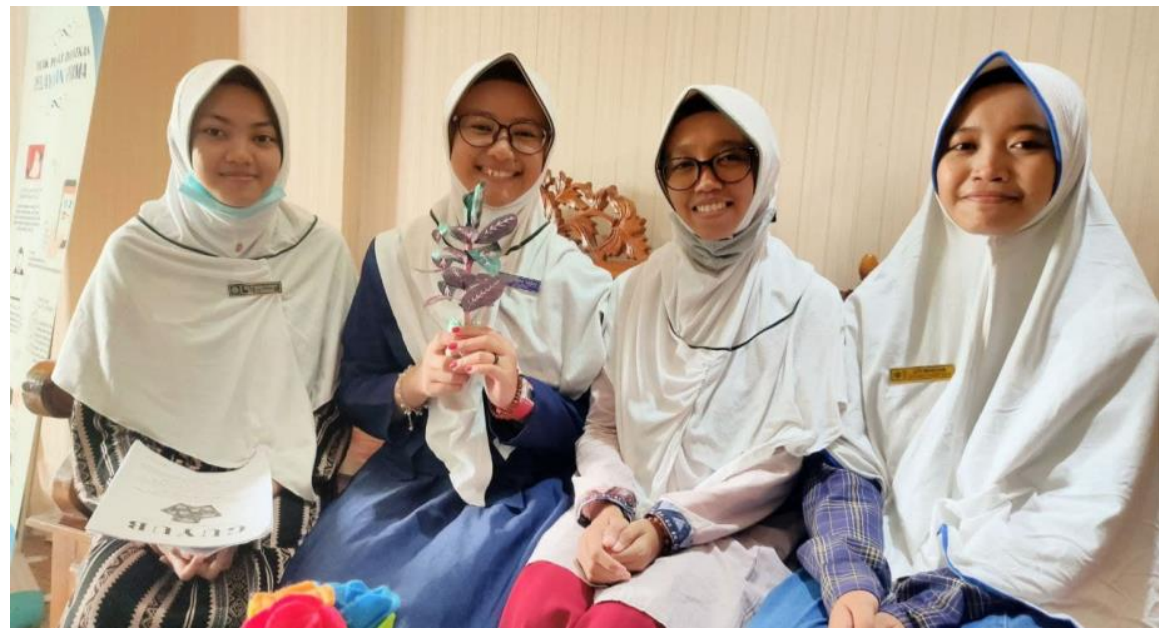

Gambar 6 : Hasil pesanan yang dihasilkan dari sampah non organik

\section{Kesimpulan}

Pada akhirnya lingkungan alam tempat kita berpijak akan terasa nyaman jika seluruh manusia yang hidup di dalamnya saling bahu membahu menciptakan keseimbangan antara alam dan penghuninya. Usaha mengelola sampah dengan metode ecobrick diharapkan dapat menjadi salah satu solusi untuk mengurangi limbah plastik dengan cara memanfaatkannya menjadi berbagai macam kerajinan tangan seperti pot Bunga atau furnitur (kursi, meja), ruang tanam, dinding, bahkan sebuah bangunan secara utuh. Sehingga, metode ecobrick ini dapat mengurangi pencemaran plastik di lingkungan sekitar.

Diharapkan hasil dari pengabdian ini dapat dilanjutkan oleh pihak wilayah agar lingkungan tetap sehat dan indah serta mengajak santri untuk dapat menumbuhkan jiwa wirausaha

\section{Pengakuan}

Dengan adanya pengabdian ini diharapkan adanya kesinambungan antara pimpinan wilayah dan kepala pondok pesantren. Dan dengan diijinkannya pengabdian ini tidak lupa ucapan terima kasih kepada pihak santri, pimpinan 
wilayah dan kepala pondok pesantren yang telah mensukseskan kegiatan pengabdian ini.

\section{Referensi}

Antico, F. C., Wiener, M. J., Araya-Letelier, G., \& Retamal, R. G. (2017). Ecobricks: a sustainable substitute for construction materials. Revista de la Construcción. Journal of Construction, 16(3), 518-526.

Arikunto S. 2010. Prosedur Penelitian Suatu Pendekatan Praktik. Jakarta: PT Rineka Cipta

Artiningsih, NKA, 2008. Peran Serta Masyarakat Dalam Pengeloaan Sampah Rumah Tangga. Semarang: Universitas Diponegoro.

Chandra. 2006. Penghantar Kesehatan Lingkungan.EGC. Jakarta.

Febriadi, Ihsan (2019). Pemanfaatan Sampah Organik Dan Anorganik Untuk Mendukung Go Green Concept Di Sekolah. Abdimas, Papua Journal of Community Service, 1(1)

Jurnal Sains dan Teknologi Lingkungan . Volume 2, Nomor 1, Januari 2010,(2131). www.liputan6.com diakses pada tanggal 11 Juni 2019.

Maier, R., Angway, I., \& Himawati, A. (2017). Plastik, Lingkungan dan Ecobricks.

Marliani, N. (2015). Pemanfaatan limbah rumah tangga (sampah anorganik) sebagai bentuk implementasi dari pendidikan lingkungan hidup. Formatif: Jurnal Ilmiah Pendidikan MIPA, 4(2).

Pavani, P., \& Rajeswari, T. R. (n.d.). National Seminar on Impact of Toxic Metals, Minerals and Solvents leading to Environmental Pollution-2014 Journal of Chemical and Pharmaceutical Sciences IMPACT OF PLASTICS ON ENVIRONMENTAL POLLUTION. Retrieved from www.jchps.com

Pratiwi, I.H., Wignjosoebroto, S., \&Dewi, D.S. (2007). Sistem Pengelolaan Sampah Plastik Terintegrasi dengan Pendekatan Ergonomi Total Guna Meningkatkan Peran Serta Masyarakat (Studi Kasus : Surabaya). Jurusan Teknik Industri, Institut Teknologi Sepuluh Nopember (ITS) Surabaya. 
Putra, H.P., \& Yuriandala, Y.. (2010). Studi Pemanfaatan Sampah Plastik Menjadi Produk dan Jasa Kreatif.

Taufiq, Agus (2015). Sosialisasi Sampah Organik Dan Non Organik Serta Pelatihan Kreasi Sampah. Jurnal Inovasi dan Kewirausahaan, 4(1) 